\title{
KONCEPT KOMPAKTNÍHO MĚSTA: PŘÍSPĚVEK K VÝZKUMU A SPRÁVĔ
}

\section{CONCEPT OF A COMPACT-CITY: CONTRIBUTION TO RESEARCH AND ADMINISTRATION}

\author{
DOC. RNDr. MARián HALÁS, Ph.D. ${ }^{1}$ \\ Mgr. Petr KLAdiVO, Ph.D. ${ }^{1}$ \\ Mgr. PaVel ROUBÍNEK ${ }^{2}$
}
${ }^{1}$ Katedra geografie, Přrrodovědecká fakulta ${ }^{1}$ Dep. of Geography, Faculty of Science Univerzita Palackého v Olomouci Palacký University Olomouc
$\triangle$ 17. listopadu 12, 77146 Olomouc, Czech Republic
E-mail: marian.halas@upol.cz,petr-petr@email.cz

\author{
${ }^{2}$ Katedra sociální geografie a reg. rozvoje $\mid{ }^{2}$ Dep. of Social Geography and Reg. Development \\ Př́rodovědecká fakulta, Ostravská univ. v Ostravě Faculty of Science, University of Ostrava \\ $\triangle$ Kranichova 8, 71000 Ostrava, Czech Republic \\ E-mail: pavel.roubinek@seznam.cz
}

\begin{abstract}
Anotace
Termín kompaktní město se v odborné literatuře zmiňuje v několika významech. Cílem př́spěvku je analyzovat některé z těchto významů a přistupů. Po zhodnoceni kompaktnosti města jako důležitého konceptu pro územni plánováni je kompaktni mésto hodnoceno jako prostor s urbánním charakterem zástavby odděleným od zástavby suburbánní a rurálni. Součástí přispěvku je i srovnání financováni a správy sídel v těsném zázemi kompaktního města. Pro vymezeni kompaktního města na př́kladu „stotisícových měst" České republiky je použita metoda morfometrické analýzy, konkrétně vymezení prostřednictvím spojitosti GIS vrstvy budov. Kompaktnost sídel je důležitým předpokladem souvisejícím s kvalitou života. Suburbánní zástavbou nespojitá sídla v zázemí kompaktního města by taktéž měly být kompaktní ve svém intravilánu, a zároveň maji výhodu alternativ pro své financování a správu.
\end{abstract}

\section{Klíčová slova}

kompaktní mésto, morfometrická analýza, kvalita života

\section{Annotation}

The term compact-city exists in literature in several meanings. The aim of this paper is to analyse some of these meanings and approaches. After considering the compactness of a city as an important concept for area planning, the compact-city is evaluated as an area of urban character of housing development separated from suburban and rural development. A part of this paper is also represented by comparison of funding and administration of settlements in close surrounding of the compact-city. To define the compact city on the example of 'hundreds-of-thousands cities' of the Czech Republic, the method of morphometric analysis is applied, more specifically delimitation through connection of GIS layer of buildings. The settlements compactness is an important condition connected with life quality. Suburban areas in the hinterland of the compact-city with discontinuous building development should be also compact in their urban areas and their advantage is also an alternative for their funding and administration. 


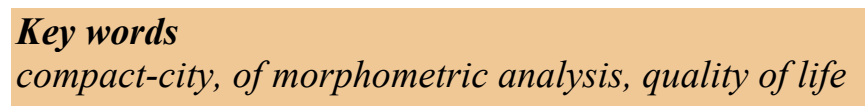

JEL classification: $R 21, R 51$

\section{Úvod}

Rozrůstání území města a zabírání okolní zemědělské půdy začalo mít po roce 1990 i v České republice často až nekontrolovatelný charakter. Proto se můžeme stále častěji $\mathrm{v}$ literatuře setkat $\mathrm{s}$ termínem kompaktní město, a to hned v několika rozdílných, ale souvisejících významech. Cílem tohoto př́spěvku je analyzovat některé $\mathrm{z}$ těchto významů a alternativních př́istupů. Po zhodnocení kompaktnosti města jako důležitého konceptu pro územní plánování, je kompaktní město označováno jako území s urbánním charakterem zástavby. Takto chápaný prostor byl po staletí jednoznačně oddělený od zástavby rurální. V posledním období se hlavně v souvislosti se suburbanizačními procesy zástavba $\mathrm{v}$ zázemí velkých měst rozvolňuje, zabírá plošně velká území a v horším případě se stává chaotickou. Součástí př́íspěvku je i vymezení kompaktního města na př́ikladu „stotisícových měst“ České republiky za použití metody morfometrické analýzy. V závěrečné části jsou stručně srovnávány možnosti financování a správy sídel v těsném zázemí kompaktního města.

\section{Kompaktní město jako cíl územního plánování}

Primární význam termínu kompaktní město souvisí s urbanismem a v odborné literatư̌e je používán ve spojitosti se zachováním kompaktnosti urbánního prostoru za pomoci nástrojủ územního plánování. Je součástí politiky udržitelnosti při řízení nebo plánování městského prostoru (Halás, 2003). V souvislosti s kompaktním městem se řeší témata jako omezení sílící automobilové dopravy ve městech, snížení emisí a znečištění ovzduší, revitalizace a opětovné využívání městských brownfields, rozvoj veřejné dopravy nebo tzv. inteligentní růst města se zaměřením na energetické úspory zásluhou kompaktnosti uspořádání urbánního prostoru. V souvislosti $\mathrm{s}$ udržitelností měst a ekologickými přístupy se termín kompaktní město objevuje již v 70. letech 20. století (Dantzig, Saaty, 1973), širší pozornosti se mu ale dostává až po intenzivnějším nárůstu urban sprawl koncem 80 . let a v 90 . letech (např. Brehemy, 1995). Navzdory dlouhotrvajícím diskusím se kompaktní město nakonec stalo součástí mnohých vládních iniciativ napřs. ve Velké Británii a Nizozemsku (Buček, et al. 2010).

V Nizozemsku byla od konce 70. let oficiálně zavedena tzv. politika kompaktního města. Díky tomu zaznamenáváme od 80. let rozkvět, obrodu a růst holandských měst jako Amsterdam, Rotterdam a Haag (Faludi, Van der Valk, 1994; Turok, Mykhnenko, 2007). Po éře rozvolněné suburbanizace dochází cíleně k návratu obyvatel do měst a jejich center, tedy k reurbanizaci. Součástí této politiky je opětovné využívání brownfieldů a výstavba nových domů na předem připravených pozemcích $\mathrm{v}$ zastavěných oblastech měst. Politika kompaktního města může řešit některé, ale ne zcela všechny problémy ve městech (Healy, Birrell, 2004). Snižuje přepravní vzdálenosti pro přepravu osob a při vytažení vysokokapacitních komunikací ven z měst může vytvářet lepší podmínky pro ekologické druhy dopravy (např. městské cyklostezky) i celkový přesun dopravních preferencí směrem $\mathrm{k}$ nemotorovým vozidlům (Maat et al. 2005; Gehl, 2010; z českých autorů Hnilička, 2005).

Rozrůstání území města a zabírání okolní zemědělské půdy má někdy až nekontrolovatelný charakter. Pro již zmíněný termín urban sprawl se v češtině začalo používat pojmenování sídelní kaše (Hnilička, 2005). Většina odborníků tvrdí, že vyšší hustota zástavby je pro městský prostor nevyhnutná a je nutnou podmínkou udržitelného rozvoje měst. V souvislosti s tímto tvrzením upozorňují McEldowney et al. (2005) na nutnost urbanistů a plánovačů prokázat, že oblasti s vysokou hustotou zástavby mohou být atraktivní a výhodnou lokalitou pro život obyvatel ve všech fázích jejich životního cyklu.

Skutečnost, že rozrůstání území měst, suburbanizace a urban sprawl zvýšily intenzitu používání motorových vozidel, a to hlavně pro přsuny mezi místem bydlení a zaměstnání, potvrzuje mnoho 
výzkumů (Brueckner, 2000, Glaeser, Kahn, 2004). Kahn (2006) uvádí, že průměrná spotřeba benzínu na jednu domácnost je v USA nejnižší v relativně kompaktních městech, jako je New York a San Francisco a nejvyšší v rozlehlých městech, jako je Atlanta a Houston. Zatímco environmentální náklady rozrůstání měst byly v Severní Americe neustále zkoumány, tato otázka se stává důležitou i v Evropě. Např́klad mezi lety 1986 a 1996 se v metropolitní oblasti Barcelony úroveň emisí na obyvatele zdvojnásobila, průměrná denní přepravní vzdálenost zvýšila o $45 \%$ a podíl výletů autem vzrostl o 62\% (Muniz, Galindo, 2005). Proto se i z pohledu environmentálních nákladů rozrůstání měst vědci a urbanisté přiklánějí spíše ke konceptu kompaktního města jako lepší alternativě $\mathrm{k}$ rozvolněné zástavbě.

Tuto výhodu nižších ekonomických a environmentálních dopravních nákladů akceptují i Gaigné, et al. (2012). Nicméně jejich výzkum př́ípadného přemístění činností ne v rámci města, ale mezi městy, upozorňuje na skutečnost, že výhoda kompaktnosti města nemusí platit. Politika kompaktního města podle jejich zjištění ovlivňuje ceny, mzdy i výšku polohové renty, což vytváří finanční tlak na firmy a domácností lokalizované v kompaktních městech a hlavně v jejich centru. I když je kompaktnost $\mathrm{z}$ ekologického hlediska spíše žádoucí, nemusí být vždy šetrná k životnímu prostředí, a to hlavně $\mathrm{v}$ př́padech, kdy je snaha ekonomickou a ekologickou rovnováhu utvářet pouze prostřednictvím politických zásahů. De Roo (2000) rovněž upozorňuje, že politika kompaktního města může paradoxně znamenat $\mathrm{z}$ určitých pohledů zvýšení negativních faktorů jako rušnost prostředí, hluk, špatná kvalita ovzduší, prach, zplodiny a znečišt’ující látky nebo vyšší riziko katastrof. Tento komplex účinků se označuje jako „paradox kompaktního města“. Řešení těchto environmentálních konflikto̊ potom vyžaduje komplexní politiku a tvorbu nejvhodnějších přístupů.

Převážná řada odborníků, urbanistů a územních plánovačů se ale shoduje na názoru, že zachování kompaktnosti městského prostoru je hlavním předpokladem pro dosažení udržitelnosti měst a $\mathrm{v}$ př́ipadě nedodržování základních principu kompaktní zástavby mají k dalšímu vývoji městského prostoru spíše skeptický pohled (Neuman, 2005).

\section{Vymezení kompaktního města}

Vymezení urbánního prostoru se u všech větších českých měst neshoduje s administrativními hranicemi těchto měst. Ve většině př́padů jsou administrativně součástí těchto měst i bývalé venkovské obce, které jsou zástavbou oddělené od samotného města a tyto sídla si i nadále uchovávají venkovský charakter. S tím počítá i většina autorů ve svých studiích a při hodnocení (sub)urbanizačních procesů se nedrží striktně administrativních hranic města, většinou však neuvádějí přesný způsob oddělení urbánního a suburbánního nebo rurálního prostoru (např. Klusáček et al. 2009; Sýkora, Posová, 2011). V př́ípadě zkoumaných stotisícových měst, kde jsou jádrová osídlení některých integrovaných bývalých samostatných obcí vzdálena i 10-12 km od centra města, vidíme jednoznačnou potřebu toto území zúžit či zmenšit, tedy použít spíše morfologické vymezení města.

Termín kompaktní město se ve světové ani v české literatuře v souvislosti s vymezením tohoto prostoru př́liš neobjevuje. Mnoho autorů pracuje spíše $\mathrm{s}$ intravilánem, což našim potřebám nevyhovuje. Intravilán obce představuje zastavěnou část území obce bez ohledu na to, jestli je toto území spojité, nebo nikoliv. Pojem samotný je však mnohdy chápán odlišně a při vymezení měst na základě tohoto morfologického přístupu je pak také jeho aplikace rozdílná. Sýkora, Posová (2011) např. hovoří o morfologicky definovaných kompaktních celcích městského intravilánu, což je souvisle zastavěné funkčně integrované území. Ouředníček et al. (2008) zase uvádí definici kompaktního města pouze jako „souvisle zastavěné území“. V zahraniční literatuře se vyskytuje vysvětlení nebo definic více, jedna z nich ř́íká, že kompaktním městem se rozumí území s vysokou hustotou zalidnění, podílem zastavěných ploch $\mathrm{s}$ různým charakterem jejich využití a je obsluhováno efektivním systémem veřejné dopravy (Burton, 2000). Na problematiku nesouladu mezi administrativním vymezením a skutečným rozsahem města upozorňoval např. už Korčák (1963), který hovoří o analyticky správnějším a přsesnějším vymezení jádra na základě analýzy morfologie zástavby při respektování funkční integrity územních vazeb. Za jádro městského regionu je považováno kompaktní město ve smyslu souvisle urbanizovaného území města, jehož součástí mohou být i rozsáhlé 
nezastavěné plochy, např. parků, jejichž intenzivní využívání městskou populací je funkčně integruje do jádra metropolitního území. Takový pohled se liší od př́stupu aplikovaného např́íklad v Územně analytických podkladech k novému územnímu plánu hlavního města Prahy (z roku 2008), kde se zdůrazňuje souvisle zastavěné území, jež však nezahrnuje území parků, např. Stromovky. Otázkou je, zda je vhodné při definování jádra metropolitní oblasti nebo kompaktního města funkční hledisko opomíjet. Útvar rozvoje hlavního města Prahy při tvorbě urbanistických koncepcí pojem kompaktní město taktéž využívá, dokonce na území Prahy vymezuje kompaktní město vnitřní a vnější, ale detailně ho nedefinuje. Není tak jasné, které pozemky do kompaktního města patř́ a které už ne, kde zvolit hranici.

Ve vědecké literatuře nacházíme velké množství titulů, které mají ambici kvantifikovat oddělení urbánního a rurálního prostředí (de facto vymezit prostor města či kompaktního města), prííp. zachytit tzv. urbánně-rurální kontinuum nebo komplementaritu. Tyto práce vycházejí především ze sofistikovaných kvantitativních metod. Většinou se jedná o měření měr koncentrace, resp. rozptýlenosti (rovnoměrné i nerovnoměrné) sídelního systému, pro které Burt, Barber (1996) vyčleňují dvě skupiny metod: metody vycházející z areálových dat a metody vycházející z bodových dat. Mezi autory využívající obě skupiny metod patří např. Fotheringham et al. (2000) nebo Schabenberger, Gotway (2005). Na území Slovenska, a to $\mathrm{v}$ oblastech s rozptýlenými i koncentrovanými sídly, aplikoval metody měření kompaktnosti a koncentrovanosti osídlení Hurbánek (2005a, 2005b, 2008).

Pro vymezení kompaktního města jsme použili morfometrické analýzy, konkrétně vymezení prostřednictvím GIS vrstvy budov. Vytvořili jsme tak souvisle zastavěné území, kde není proluka mezi sousedními budovami d větší než 250 metrů. Určení optimální vzdálenosti d nebylo jednoduché, snažili jsme se pro něj stanovit maximální hodnotu tak, aby vzniklé vymezení bylo spojité a zároveň relativně kompaktní. Při použití menší hodnoty se vně kompaktního města ocitly i očividně integrované zóny. Stanovenou hodnotu jsme testovali na Praze a všech krajských městech a ve všech př́padech se ukázala jako použitelná. Určité problémy nastaly u řek protékajících městy. Ty mají spolu s nábřežím někdy větši šiřrku než 250 metrů a při použití stanovené metody by rozsekly některá města (např. Prahu, České Budějovice, Pardubice nebo Ústí nad Labem) na dvě části. $Z$ toho důvodu vstupovala plocha řeky do morfometrické analýzy stejným způsobem jako zastavěné území. Vymezení kompaktního města pro šest cca „stotisícových měst“ (České Budějovice, Hradec Králové, Liberec, Olomouc, Pardubice a Ústí nad Labem) je znázorněné na obr. 1. Podíly vymezených kompaktních měst na obyvatelstvu měst v administrativním vymezení jsou v tab. 1.

Z populačních charakteristik stotisícových měst je patrné, že cca 3-6\% obyvatel (nebo cca 3-6 tisíc obyvatel) města v administrativním vymezení žije v sídlech mimo kompaktní město. Výjimkou je Ústí nad Labem (cca 15\% obyvatel mimo kompaktní město), kde byly původní obce Neštěmice a Mojžíř zahuštěny panelovou zástavbou, která doposud ještě zcela nesrostla s kompaktním městem. Tato dvě sídliště mají spolu s původní venkovskou zástavbou až 10,2 tis. obyvatel. V ostatních případech jsou mimo kompaktní město spíše menší sídla rurálního nebo suburbánního charakteru, které mají většinou do 1000 obyvatel. Nicméně jejich vzdálenost od centra města je už v těchto př́ípadech větší (Lošov je vzdálen $13 \mathrm{~km}$ a Radíkov $12 \mathrm{~km}$ od centra Olomouce; Opočínek $12 \mathrm{~km}$ a Lány na Důlku $10 \mathrm{~km}$ od centra Pardubic, Kaliště $9 \mathrm{~km}$ a Třebotovice $8 \mathrm{~km}$ od centra Českých Budějovic apod.). Nejvíce takovýchto sídel mají ve svém zázemí Hradec Králové a Pardubice. Při sídlech bližších kompaktnímu městu je ale nutné brát hodnocení s rezervou. Byla totiž použita vrstva z roku 2007 a při současné intenzitě výstavby $v$ okrajových částech města je předpoklad, že nejbližší sídla časem splynou s kompaktním městem stejně tak, jak splynula mnohá původně venkovská sídla v období socialismu. Vývoj zástavby $\mathrm{v}$ okrajových částech měst je stále dynamický proces, který není možné v žádném prípadě považovat za ukončený. 
Obr. 1: Vymezení kompaktního města ve srovnání s administrativním vymezením: a) Č. Budějovice, b) H. Králové, c) Liberec, d) Olomouc, e) Pardubice, f) Ústí nad Labem
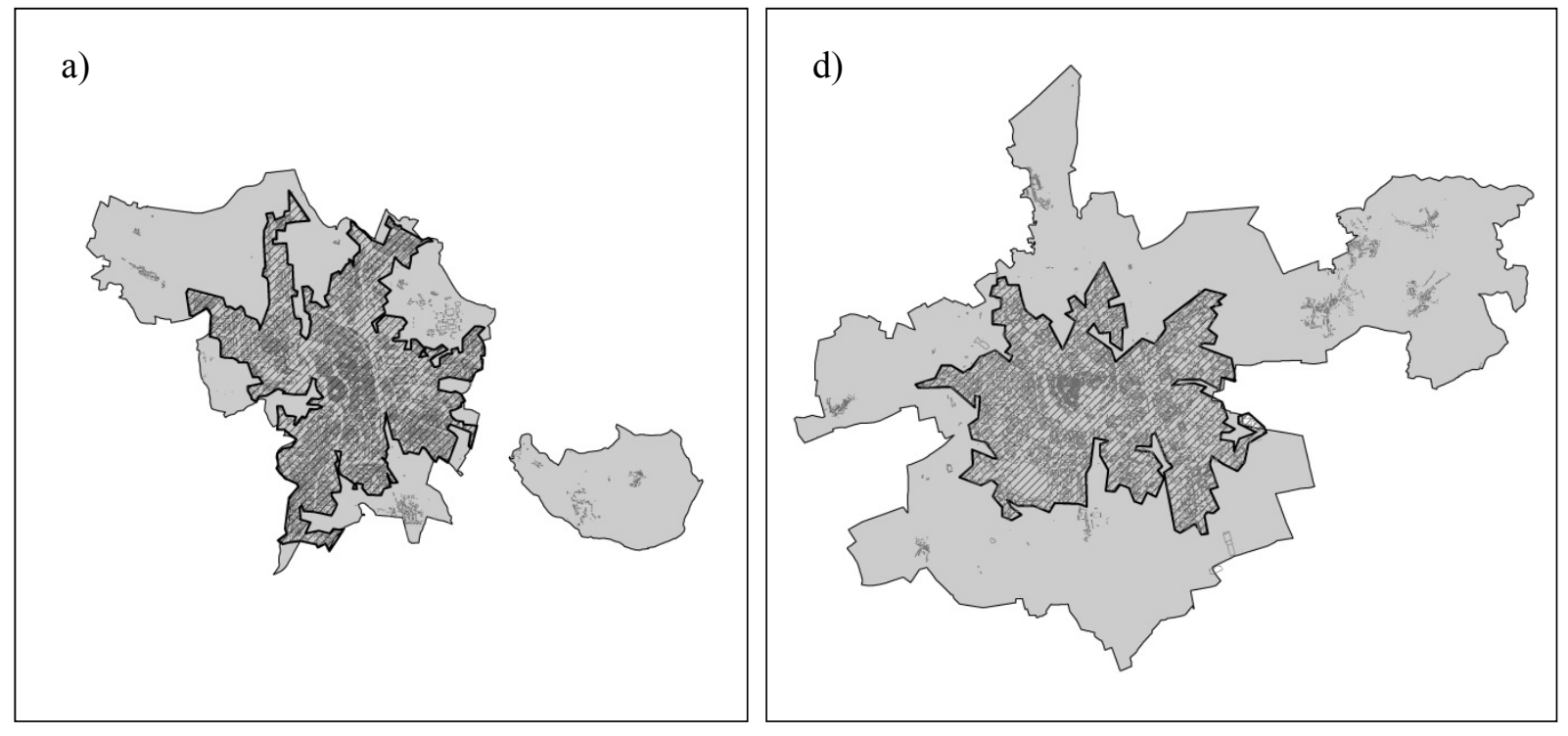

b)

e)

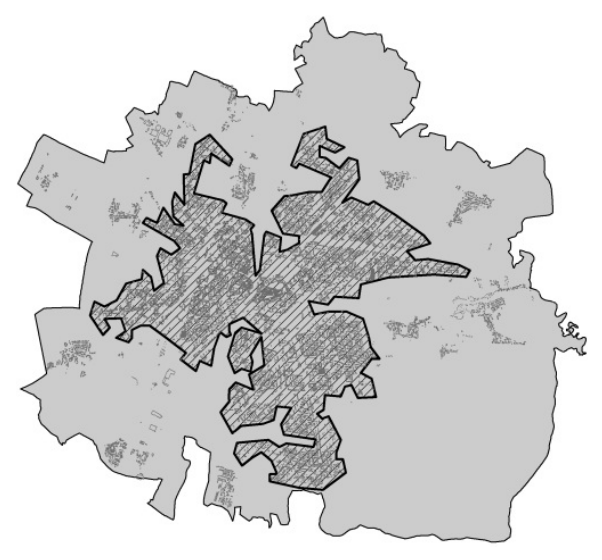

c)

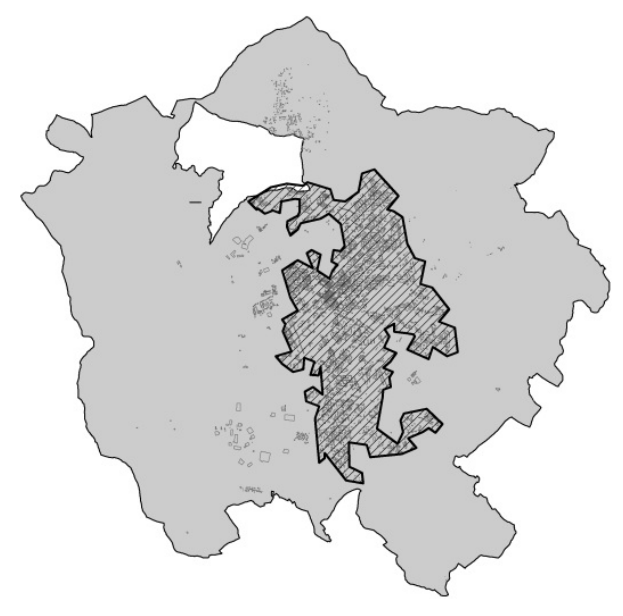

f)

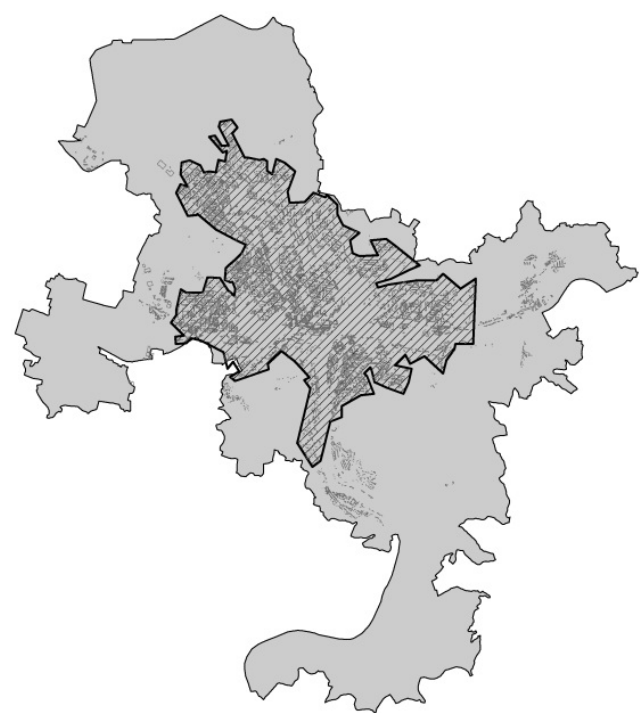

Zdroj: vlastní zpracování 
Tab. 1: Populační velikosti vymezených kompaktních měst vzhledem $k$ administrativním městům

\begin{tabular}{|c|c|c|c|c|}
\hline \multirow[b]{2}{*}{ město } & \multicolumn{3}{|c|}{ obyvatelstvo (tis.) } & \multirow[b]{2}{*}{$\begin{array}{c}\text { podíl KM na } \mathrm{AM} \\
(\%)\end{array}$} \\
\hline & $\begin{array}{l}\text { město } \mathrm{v} \text { admin. } \\
\text { vvymezení (AM) }\end{array}$ & $\begin{array}{l}\text { kompaktní } \\
\text { město }(\mathrm{KM})\end{array}$ & $\begin{array}{c}\text { největší ZSJ } \\
\text { mimo KM }\end{array}$ & \\
\hline Olomouc & 101,4 & 95,5 & 1,0 & 94,2 \\
\hline Liberec & 98,1 & 94,7 & 0,9 & 96,5 \\
\hline České Budějovice & 96,8 & 94,1 & 0,8 & 97,2 \\
\hline Hradec Králové & 95,9 & 90,0 & 1,1 & 93,8 \\
\hline Ústí nad Labem & 93,9 & 79,3 & 3,5 & 84,4 \\
\hline Pardubice & 89,3 & 85,5 & 0,9 & 95,7 \\
\hline
\end{tabular}

Větší sídla, která jsou morfologicky oddělená od kompaktního města a tvoří de facto samostatné, prostorově oddělené jednotky, by měla mít dle našeho názoru ve statutárních městech i vlastní samostatně volenou samosprávu, což se ale v některých případech neděje. Ze stotisícových měst mají vlastní samosprávu na nižší úrovni Liberec (mají specifický způsob řízení pouze s jedním městským obvodem, zbytek podléhá př́mo orgánům města), Pardubice ( 8 městských obvodů) a Ústí nad Labem (4 městské obvody). České Budějovice, Hradec Králové a Olomouc samosprávu na nižší úrovni nemají a sídla morfologicky nespojitá jsou řízena z centrální úrovně magistrátem. Nicméně tato sídla mají navzdory jistým legislativním omezením alternativu, zda chtějí být součástí těchto měst nebo zda chtějí být samostatné. Obě varianty se liší způsobem řízení i způsobem financování. Pokud jsou součástí většího města, dostávají sice vyšší objem financí v přepočtu na obyvatele (v rámci pravidel rozpočtového určené daní), ale na druhou stranu nemají reálný vliv na přerozdělování těchto prostředků v rámci města.

\section{Závěr}

Použitý koncept kompaktního města aplikovaný na stotisícová města poukázal na jev typický pro Českou republiku, tedy na širší vymezení měst. Většina z nich zahrnuje kromě vlastního „reálného“ a morfologicky jasně uchopitelného městského prostoru i jednotky rurálního nebo suburbánního charakteru, morfologicky oddělené od typické městské zástavby. Jedná se z větší části o obce integrované v 70. a 80. letech 20. století v souvislosti s realizací střediskové soustavy osídlení. Některé $\mathrm{z}$ těchto sídel už srostly zástavbou s kompaktním městem a některé v blízkosti hranic kompaktního města v nejbližším období pravděpodobně srostou. Stále je však dost sídel (většinou menších, do 1000 obyvatel), která mají venkovský charakter, jsou ve větší vzdálenosti od kompaktního města, ale administrativně jsou jeho součástí (hlavně v Hradci Králové, Olomouci a Pardubicích). Takto vymezené administrativní hranice stotisícových měst však není nutno podrobovat pouze kritice. Sídla ležící v urbánně nespojitém území měst mají možnost alternativy, setrvat jako součást města nebo se odčlenit, pokud to považují za výhodné. Problémem pro ně spíše může být, že v př́ipadě že jsou administrativně součástí města, nemusí mít vždy vlastní samosprávu.

\section{Literatura}

[1] BREHEMY, M. The compact city and trasport energy consumption. Transactions of the Institute of British Geographers, 1995, 20, 81-101. DOI: 10.2307/622726.

[2] BRUECKNER, J. K. Urban sprawl: diagnosis and remedies. International Regional Science Review, 2000, 23, 160-171. DOI: 10.1177/016001700761012710.

[3] BUČEK, J., BORÁROSOVÁ, Z., SOPKULIAK, A. Miestne financie a miestny ekonomický rozvoj. Geo-grafika, Bratislava, 2010.

[4] BURTON, E. The compact city: just or just compact? A preliminary analysis. Urban Studies 2000, 37 (11), 1969-2006

[5] BURT, J. E., BARBER, G. M. Elementary statistics for geographers. , The Guilford Press, New York, 1996. 
[6] DANTZIG, G. B., SAATY, T. L. Compact city: A plan for a liveable urban environment. W. H. Freema, San Francisco, 1973.

[7] DE ROO, G. Environmental conflicts in compact cities: complexity, decision-making, and policy approaches, Environment and Planning B: Planning and Design 20000, 27, 151-162.

[8] FALUDI, A., VAN DER VALK, A. J. Rule and Order: Dutch Planning Doctrine in the Twentieth Century. Kluwer Academic, Dordrecht, 1994.

[9] FOTHERINGHAM, A. S., BRUNSDON, C., CHARLTON, M. E.. Quantitative geography: Perspectives on spatial data analysis. Sage Publications, London, 2000.

[10] GAIGNÉ, C., RIOU, S., THISSE, J. F. Are compact cities environmentally friendly? Journal of Urban Economics, 2012, 72, 123-136. DOI: 10.1016/J.JUE.2012.04.001.

[11] GEHL, J. Města pro lidi. Partnerství, Brno, 2010.

[12] GLAESER, E. L., KAHN, M. E. Sprawl and urban growth. In: Henderson, J. V., Thisse, J. F. (Eds.): Handbook of Regional and Urban Economics, 2004, Vol. 4. North Holland, Amsterdam, 2481-2527.

[13] HALÁS, M. Possibilities for the application of geography to land use planning. Acta Universitatis Carolinae, Geographica, 2003, 38 (1), 67-77.

[14] HEALY, E., BIRRELL, B. Housing and community in the compact city. Ahuri, Melbourne, 2004.

[15] HNILIČKA, P. Sídelni kaše. Otázky k suburbánni výstavbě kolonii rodinných domů. Era, Brno, 2005.

[16] HURBÁNEK, P. (2005a). Vývoj a nové prístupy v interpretáciách vidieka: priestorový aspekt, periférnost' a koncentrovanost systému osídlenia. In. Spišiak, P. et al.: Agrorurálne štruktúry Slovenska po roku 1989. Geo-grafka, Bratislava, 2005, 95-114.

[17] HURBÁNEK, P. (2005b). Vybrané priestorové atribúty systému osídlenia, ich charakteristiky a miery. Geografie XVI, Masarykova univerzita, Brno, 2005. 222-229.

[18] HURBÁNEK, P. Recent developments in definitions of rurality/urbanity. Focus on spa-tial aspect and land cover composition and configuration. Europa, 2008, XXI, 17, 9-27.

[19] KAHN, M. E. Green Cities: Urban Growth and the Environment. Brookings Institution Press, Washington, DC, 2006.

[20] KLUSÁČEK, P., MARTINÁT, S., MATZNETTER, W., WISBAUER, A. Urban development in selected Czech and Austrian city regions. Acta Universitatis Palackianae Olomucensis Geographica, 2009, 40 (2), 27-57.

[21] KORČÁK, J. Úvod do všeobecné geografie obyvatelstva. SPN, Praha, 1963.

[22] MAAT, K., VAN WEE, B., STEAD, D. Land use and travel behaviour: expected effects from the perspective of utility theory and activitybased theories. Environment and Planning B: Planning and Design, 2005, 32, 33-46.

[23] MCELDOWNEY, M., RYLEY, T., SCOTT, M., SMYTH, A. Integrating land-use planning and transportation in Belfast: a newpolicy agenda for sustainable development? Journal of Environmental Planning and management, 2005, 48, 507-526.

[24] MUNIZ, I., GALINDO, A. Urban form and the ecological footprint of commuting. The case of Barcelona. Ecological Economics, 2005, 55, 499-514.

[25] NEUMAN, M. The compact city fallacy. Journal of Planning Education and Research, 2005, 25, 11-26. DOI: 10.1177/0739456X04270466.

[26] OUŘEDNÍČEK, M., TEMELOVÁ, J., MACEŠKOVÁ, M., NOVÁK, J., PULDOVÁ, P., ROMPORTL, D., CHUMAN, T., ZELENDOVÁ, S., KUNCOVÁ, I. Suburbanizace.cz. Univerzita Karlova, Praha, 2008.

[27] SCHABENBERGER, O., GOTWAY, C. A. Statistical methods for spatial data analysis. Chapman and Hall/CRC, Boca Raton, 2005.

[28] SÝKORA, L., POSOVÁ, D. Formy urbanizace: kritické zhodnocení modelu stadií vývoje měst a návrh alternativní metody klasifikace forem urbanizace. Geografie, 2011, 116 (1), 1-22.

[29] TUROK, I., MYKHNENKO, V. The trajectories of European cities, 1960-2005. Cities, 2007, 24 (3), 165-182.

Př́spěvek byl zpracován v rámci projekntu č. P404/11/1811 Grantové agentury České republiky „Urbánní a suburbánní kvalita života: geografický pohled“. 